\title{
Production of High-Strength Coke from Low-Quality Coals Chemically Modified with Thermoplastic Components
}

\author{
Naoto Tsubouchi ${ }^{1)^{*}}$, Ryo Naganuma ${ }^{1)}$, Yuuki Mochizuki ${ }^{1)}$, Hideyuki Hayashizaki ${ }^{2)}$, \\ Takahiro SHISHIDO ${ }^{3)}$ and Atul SHARma ${ }^{4)}$ \\ 1) Center for Advanced Research of Energy and Materials, Faculty of Engineering, Hokkaido University \\ 2) Process Research Laboratories, Nippon Steel Corporation \\ 3) Coal \& Energy Project Dept., Technical Development Group, Kobe Steel, Ltd. \\ 4) National Institute of Advanced Industrial Science and Technology (AIST)
}

Abstract: In order to produce high-strength coke from low-quality coals, noncovalent bonds between O-functional groups in coal were cleaved by pyridine containing HPC pyridine soluble and HPC-derived thermoplastic components were introduced into the pores formed by swelling; thus, the synergistic effect during carbonization of the suppression of cross-linking reactions and the fluidity amplification due to close placement of coal and thermoplastic components was investigated. When HPC was extracted with pyridine, a decrease in O-functional groups was observed in the pyridine-soluble and pyridine-insoluble components. When HPC was extracted with $\mathrm{MeOH}$, on the other hand, O-functional groups in HPC selectively moved into the soluble components. When non- or slightly-caking coal was chemically-modified with the prepared HPC pyridine-soluble components by utilizing the solvent-swelling effect of pyridine, the fluidity improved compared with the coals physically mixed with the soluble components or HPC. On the other hand, the fluidity of the chemically-modified sample with the $\mathrm{MeOH}$-soluble components hardly changed from that of the original sample, and no effect of the modification with the thermoplastic component was observed. Furthermore, it was clarified that higher-strength coke can be produced from the chemically-modified sample with the HPC pyridine-soluble components than from the original coal or the physically mixed coal with the soluble components. The contraction behavior during carbonization of the chemically-modified sample with the soluble components and that of the original coal was investigated; as a result, a large difference was not observed between these two. Thus, it was found that high-strength coke can be produced from low-quality coals by the present method.

Keywords: coal; coke; chemically modified; thermoplastic components; coke strength.
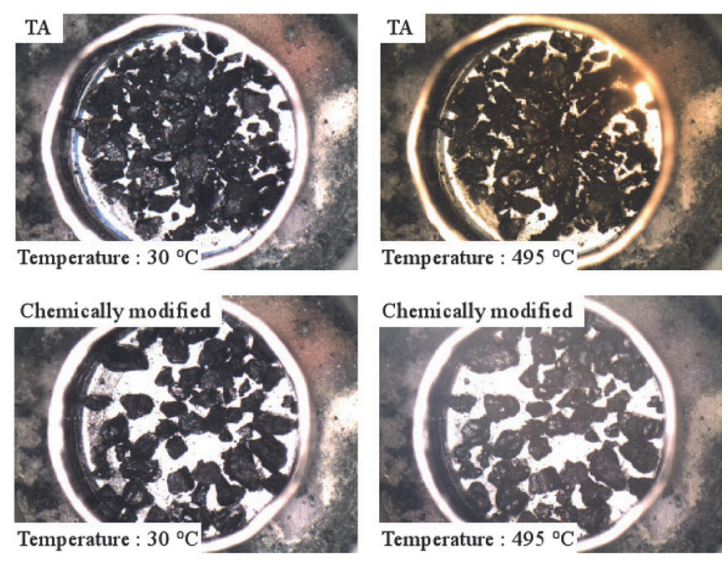

Received on Jun. 11, 2020 ; Accepted on Sep. 16, 2020 ; J-STAGE Advance published on Oct. 28, 2020 ; originally published in ISIJ Int., Vol.59, 2019, No.8, pp.1396-1403

* Corresponding author. E-mail : tsubon@eng.hokudai.ac.jp, Address : Hokkaido University, Kita 13 Nishi 8 Kita-ku Sapporo Hokkaido 060-8628

(c) (i) $\odot 2021$ The Iron and Steel Institute of Japan. This is an open access article under the terms of the Creative Commons Attribution-NonCommercialNoDerivatives license (https://creativecommons.org/licenses/by-nc-nd/4.0/). 


\title{
軟化溶融成分を化学的に担持した劣質炭からの 高強度コークスの製造
}

\author{
坪内 直人 ${ }^{1) *}$. 永沼 遼 $^{1)} \cdot$ 望月 友貴 ${ }^{1)} \cdot$ 林崎 秀幸 ${ }^{2)} \cdot$ 宍戸 貴洋 ${ }^{3)} \cdot$ Atul Sharma $^{4)}$
}

Production of High-Strength Coke from Low-Quality Coals Chemically Modified with Thermoplastic Components

Naoto Tsubouchi, Ryo Naganuma, Yuuki Mochizuki, Hideyuki Hayashizaki, Takahiro Shishido and Atul Sharma

\section{1. 緒言}

製鉄用コークスには，高炉の低還元剂比操業による $\mathrm{CO}_{2}$ 排出量削減を実現するため更なる強度増大が望まれてい る。しかし，その原料となる良質な粘結炭は，近年のアジ ア諸国に打ける鉄鋼需要の増加にともない使用量が増して いる。そのため，良質な粘結炭の価格高騰と枯渇が懸念さ れている。従って，コークス製造用石炭資源拡大の観点か ら, 安価で埋蔵量が豊富な劣質炭 (非微粘結炭や非粘結炭 (亜れき青炭など)）からのコークス製造技術の開発が重要 である。

近年, 軟化溶融特性を有する石炭溶剂抽出成分 (HPC： Hyper Coal）を劣質炭に添加し，粘結炭の使用量を低減可 能なコークス製造法の開発が進められている ${ }^{1)}$ 。一方で, 劣質炭中に非共有結合を介して多く含まれる含酸素官能基 は, 乾留時に容易に分解し, 流動性低下の主原因となる架 橋を形成する。そのため，溶融性向上のためには加熱時の 架橋反応を抑制する必要がある ${ }^{2,3)}$ 。よく知られているよう に，非共有結合はピリジン等の高極性溶媒により容易に切 断され，その結果生じる石炭/チャーの膨潤現象の程度か ら, 非共有結合の相対的存在量と加熱時の架橋進行を見積 もることが出来る ${ }^{4,5)}$ 。既往の研究に従えば, 石炭中の炭素 含有量と溶媒抽出率ならびに溶媒膨潤率の間には相関関係 が存在し，後者2つは使用する溶媒に依存する ${ }^{6-8)}$ 。また， 炭素含有量と架橋点間分子量プロットでは，炭素含有量が 86-87 mass\%-dafで最大值が認められている9,10)。さらに, Illinois No.6炭のピリジン抽出残椬を種々の有機溶媒に浸 したときの膨潤值と溶媒の溶解度パラメーターを調べた報
告に従えば，ペンタン，ベンゼン， $\mathrm{CS}_{2}$ などの非極性溶媒と 比較し, DMSO, THF，ピリジンなどの極性溶媒は高い膨潤 值を示し，試験した溶媒のなかで最も高い值を示すのはピ リジンである7 。このような溶剤による石炭の膨潤作用を 利用し，溶剤を石炭中に導入した試料を迅速熱分解するこ とで有用成分収率を増大させる試みがなされている ${ }^{11,12)}$ これは溶剤処理により溶剂分子程度のミクロ細孔を押し広 げて石炭を膨潤させ, 溶骫と石炭の近接化により石炭・溶 剤の分解速度を合致させることで溶剤由来のラジカルと石 炭フラグメントの反応を促進させるものである。また，膨 潤作用により石炭内の非共有結合 (水素結合) が解放され, その後の熱分解で架橋形成反応が抑制されることが明らか になっている ${ }^{13)}$ 。らに，ピリジンを用いると低温から架 橋反応を抑制して石炭抽出率を向上できることも報告され ている ${ }^{14)}$ 。このような既往の報告に基づき, 溶媒膨潤によ り石炭中の非共有結合を解放し, さらにコークス製造に重 要と考えられている軟化溶融成分を膨潤作用により生成し た石炭の空隙内に充填させることができれば，その後の乾 留過程での架橋形成の抑制と石炭と軟化溶融成分の近接化 により，高強度コークスが製造できる可能性がある。

そこで本研究では，ピリジンによる石炭中の含 $\mathrm{O}$ 官能 基同士の非共有結合開裂と膨潤により生成した間隙内に $\mathrm{HPC} 由$ 来の軟化溶融成分を導入し, 乾留時の架橋反応抑制 と軟化溶融成分 - 石炭間の近接化による流動性増幅の相乗 効果を図り，高強度コークス製造法を検討することを主な 目的とした。

原著論文: ISIJ Int., Vol.59 (2019), No.8, pp.1396-1403

2020年6月11日受付２020年9月16日受理２020年10月28日J-STAGE早期公開 (Received on Jun. 11, 2020; Accepted on Sep. 16, 2020；J-STAGE Advance published on Oct. 28, 2020 ; originally published in ISIJ Int., Vol.59, 2019, No.8, pp.1396-1403)

1）北海道大学大学院工学研究院附属エネルギー・マテリアル融合領域研究センター（Center for Advanced Research of Energy and Materials, Faculty of Engineering, Hokkaido University)

2) 日本製鉄 (株) プロセス研究所 (Process Research Laboratories, Nippon Steel Corporation)

3）(株) 神戸製鋼所技術開発本部機械研究所資源プロセス研究室 (Coal \& Energy Project Dept., Technical Development Group, Kobe Steel, Ltd.)

4）独立行政法人産業技術総合研究所（National Institute of Advanced Industrial Science and Technology (AIST))

* Corresponding author. E-mail : tsubon@eng.hokudai.ac.jp, Address : Hokkaido University, Kita 13 Nishi 8 Kita-ku Sapporo Hokkaido 060-8628 


\section{2. 実験}

\section{$2 \cdot 1$ 試料}

新規コークス製造プロセス要素技術研究会から提供され

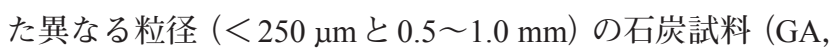
$\mathrm{TA}, \mathrm{KP})$ と $\mathrm{HPC}(<250 \mu \mathrm{m})$ を主に使用した。使用した石 炭の分析值を Table 1 に示す。そのCと Oの量は各々 74 88 と 5〜 19 mass\%-dafであった。粒径が 0.5-1.0 mmの石炭は コークス製造用に用いた。

\section{$2 \cdot 2$ 化学的担持炭の調製}

$\mathrm{HPC}$ 可溶分の化学的担持炭の調製では, 先ずHPC $1 \mathrm{~g}$ に $40 \mathrm{~mL}$ のピリジンを添加し, 室温にて $30 \mathrm{~min}$ 超音波照射し た。その後, $3500 \mathrm{rpm}$ で $10 \mathrm{~min}$ 遠心分離し, 混合物をピリ ジン不溶分 (沈降した固体) とピリジン可溶分 (上澄み液) とに分離回収した。回収した不溶分に再度ピリジンを添加 し，上記抽出操作をピリジン溶液が透明になるまで繰り返 し行なった。回収した不溶分残椬は，上述した超音波と遠 心分離によるアセトン洗浄を行なった後に抽出率を算出 するために重量測定した。ピリジン不溶分から推算した可 溶分収率は 15 mass\%であった。次に, 得られたピリジン 可溶分溶液中に TA, KPを添加し, 室温で $24 \mathrm{~h}$ 擋拌するこ とで石炭の膨潤と可溶分の担持を行なった。その後, 減圧 下， $60^{\circ} \mathrm{C}$ でピリジンを除去して HPCピリジン可溶分を化学 的に担持させた試料を得た。可溶分担持量は石炭に対し 15 〜30 mass\%の範囲であり, 可溶分溶液と石炭の添加量の比 を変化させることにより制御した。さらに, ピリジン可溶 分のキャラクタリゼーションのため, 石炭を添加せず, 可 溶分溶液中のピリジンを減圧除去して, 固体の可溶分を得 た。また，比較のため，石炭に対して膨潤作用のあるメタ ノール $(\mathrm{MeOH})$ を用いて, 上記と同様の操作を行ない実 験に供した。 $\mathrm{MeOH}$ 可溶分の収率は10 mass\%である。尚， $\mathrm{MeOH}$ 可溶分担持量は $10 \mathrm{mass} \%$ とした。

既往の報告に従い ${ }^{15)}$ ，使用した石炭の溶媒膨潤率を求め ようとしたが，膨潤過程で石炭の溶媒可溶分成分の溶出に より膨潤率を求めることは不可能であった。そこで，既往 の報告に基づき，使用した有機溶媒による各石炭試料の膨 潤率の推算を行なった。炭素含有量の異なる石炭と種々の 溶媒を用いた時の溶媒膨潤率との関係を調べた先の研究 に従えば, TA炭のC\%-daf (83.5 mass\%-daf) でのメタノー

Table 1. Analyses of samples used in this study.

\begin{tabular}{|c|c|c|c|c|c|c|c|c|}
\hline \multirow[t]{2}{*}{ Sample } & \multicolumn{5}{|c|}{$\begin{array}{l}\text { Elemental analysis } \\
\text { mass } \% \text {-daf }\end{array}$} & \multicolumn{3}{|c|}{$\begin{array}{l}\text { Proximate analysis } \\
\text { mass } \% \text {-dry }\end{array}$} \\
\hline & $\mathrm{C}$ & $\mathrm{H}$ & $\mathrm{N}$ & S & $\mathrm{O}^{\mathrm{a}}$ & Ash & $\mathrm{VM}^{\mathrm{b}}$ & $\mathrm{FC}^{\mathrm{b}, \mathrm{c}}$ \\
\hline KP & 73.6 & 5.5 & 1.5 & 0.7 & 18.7 & 5.8 & 42.9 & 51.3 \\
\hline TA & 83.5 & 5.1 & 2.0 & 0.4 & 9.0 & 6.2 & 37.5 & 56.3 \\
\hline GA & 88.1 & 5.0 & 1.8 & 0.6 & 4.5 & 11.3 & 23.4 & 65.3 \\
\hline HPC & 87.8 & 4.9 & 1.6 & 0.7 & 5.0 & 1.6 & 46.5 & 51.9 \\
\hline
\end{tabular}

a Estimated difference. ${ }^{\mathrm{b}}$ Volatile matter. ${ }^{\mathrm{c}}$ Fixed carbon.
ルによる膨潤率は 1.05 と推算される ${ }^{16)}$ 。一方, KPならびに TA炭と同程度の炭素含有量 (79.8-83.1 mass\%-daf) の石炭 のピリジン抽出残椬の膨潤率はそれぞれ約 2.4 と 2.35 と見 積もられるため, KP と TA炭も同程度の膨潤率を有するも のと考えられる

\section{$2 \cdot 3$ 乾留}

コークスの製造はSUS製焼成管で行なった ${ }^{17)}$ 。粒径 0.5 〜 $1.0 \mathrm{~mm}$ の試料を焼成管 $(\varphi 20 \mathrm{~mm} \times$ 高さ $50 \mathrm{~mm})$ 内に充 填した後, $200 \mathrm{~g}$ の荷重を掛けながらマッフル炉内で $\mathrm{N}_{2}$ 気 流中 $3^{\circ} \mathrm{C} / \mathrm{min}, 1000^{\circ} \mathrm{C}$ まで加熱し, その後 $30 \mathrm{~min}$ 保持して 焼成した。

\section{$2 \cdot 4$ キャラクタリゼーション}

入手した石炭と調製した試料の官能基分析は，フーリ 工変換赤外分光光度 (FT-IR) 計 (Jasco) で行なった。まず $\mathrm{KBr}$ と混合した試料を錠剤成型プレートに充填後，ミニプ レスで一軸加圧してペレットを調製した。その後, 試料は $5200 \sim 400 \mathrm{~cm}^{-1}$, 分解能 $0.1 \mathrm{~cm}^{-1}$, 積算回数 200 回の条件 で分析した。得られた $1800 〜 1500 \mathrm{~cm}^{-1}$ のスペクトルに対 して, 既往の報告に従い波形分離を行なった ${ }^{18)}$ 。熱重量分 析は熱天科 (Advance riko) を使用した。試料をPtパンに充 填した後, 超高純度 $\mathrm{He}(99.9995 \%)$ 中, $3{ }^{\circ} \mathrm{C} / \mathrm{min}$ で $1000^{\circ} \mathrm{C}$ まで加熱した。入手した試料ならびに調製した試料の乾留 時の軟化溶融性を調べるために, 加熱顕微鏡を用いて石炭 粒子を $50^{\circ} \mathrm{C} / \mathrm{min}$ で加熱しながら一定時間間隔で撮影を行 なった。また, 乾留時の試料の流動性と収縮挙動はギーセ ラー流動度計 (Yoshida seisakusyo) と高温ディラトメーター で調べた。それら分析手法の詳細は既報に示し通りであ る $^{19,20)}$ 。コークスの強度は圧潰強度試験装置 (Minebea) を 用いて破断時の最大荷重を測定し, 次式により間接引っ張 り強度を算出した。

$$
\mathrm{f}_{\mathrm{t}}=2 \mathrm{P} / \pi \mathrm{dl}
$$

ここで, $\mathrm{f}_{\mathrm{t}}$ : 引っ張り強度 $(\mathrm{MPa}), \mathrm{P}$ : 最大荷重 $(\mathrm{N}), \mathrm{d}$ : 試 料の直径 $(\mathrm{mm}), 1:$ 試料の高さ $(\mathrm{mm})$ を示す。

\section{3. 結果と考察}

\section{$3 \cdot 1$ 使用した石炭の流動性}

Fig.1に，使用した GA，TAならびにKP炭のギーセラー 流動プロファイルを示す。 $\mathrm{TA}$ は $380^{\circ} \mathrm{C}$ 以上から軟化溶融 し, $425^{\circ} \mathrm{C}$ 前後に最高流動度值 $(\mathrm{MF})$ を与えた後, $460^{\circ} \mathrm{C}$ ま

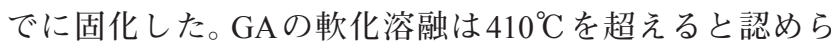
れ, その流動プロファイルは $460^{\circ} \mathrm{C} に \mathrm{MF}$ を示した。固化 温度は $490^{\circ} \mathrm{C}$ であった。一方, KP は軟化溶融性能を全く 示さなかった。 GA, TA, KPの MF值は各々2.1, 1.1, $0 \log$ (ddpm) であり, O濃度の高い石炭で低い傾向にあった。

\section{$3 \cdot 2$ HPC 可溶分と不溶分のFT-IR 分析}

石炭への膨潤作用が報告されているメタノールを用い 
てHPCの抽出を行なった時に得られた $\mathrm{MeOH}$ 可溶分と不 溶分のFT-IR 測定を行ない，観測された $1800 〜 1500 \mathrm{~cm}^{-1}$ のスペクトルに対して波形分離を行なった結果, HPCで認 められた 1700 と $1675 \mathrm{~cm}^{-1}$ 付近の $\mathrm{COOH}$ と Conjugated $\mathrm{C}=$ $\mathrm{O}$ に帰属する吸収帯は，可溶分中で大きくなった。また， $1750 \mathrm{~cm}^{-1}$ 付近にピークを有する ester, anhydrideに帰属す る吸収帯が認められた。このピークはHPCでは観測されな かったことから, 抽出により HPC 中に少量で存在した上記 種が可溶分中に濃縮したものと考えられる。一方，不溶分 では可溶分で認められた含酸素官能基 $(\mathrm{COOH}$, Conjugated $\mathrm{C}=\mathrm{O})$ は観測されなかった。これらの結果は, HPCを $\mathrm{MeOH}$ で抽出すると HPC 中の含酸素官能基が可溶分中に 選択的に移行することを示している。

Fig.2 は, FT-IRで測定したHPC, HPCピリジン可溶分, ピリジン不溶分の $1800 \sim 1500 \mathrm{~cm}^{-1}$ のスペクトルに対し て波形分離を行なった結果を示す。HPCで認められた 1700 と $1675 \mathrm{~cm}^{-1}$ 付近の $\mathrm{COOH}$ と Conjugated $\mathrm{C}=\mathrm{O}$ に帰 属する吸收帯がピリジン可溶分と不溶分では消失してい た。またHPCにおいて $1650 \mathrm{~cm}^{-1}$ 付近に観測された Highly conjugated $\mathrm{C}=\mathrm{O}$ に基因する吸収帯の面積も可溶分と不 溶分では小さくなった。このようなHPCで測定された $1700 \mathrm{~cm}^{-1}$ 前後の $\mathrm{COOH}$ や C $=\mathrm{O}$ に帰属される吸収ピーク の消失は，抽出時の石炭中の含酸素官能基同士の非共有結 合の開裂に加え，含酸素官能基と含 $\mathrm{N}$ 官能基の置換が進行 したことを示唆しているのかもしれない。既往の報告に従 えば，褐炭をピリジンで処理した際にピリジンは石炭中 の水素結合の開裂に寄与し，含酸素官能基と新たに $\mathrm{N}-\mathrm{OH}$ 水素結合等を形成する ${ }^{19)}$ 。本研究でも同様にピリジンと 含 $\mathrm{O}$ 種の相互作用が生じているものと考えられ，その結 果, HPC 中の含酸素官能基は可溶分と不溶分中に扎いて消

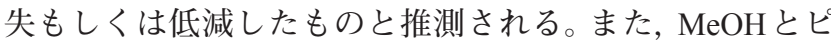

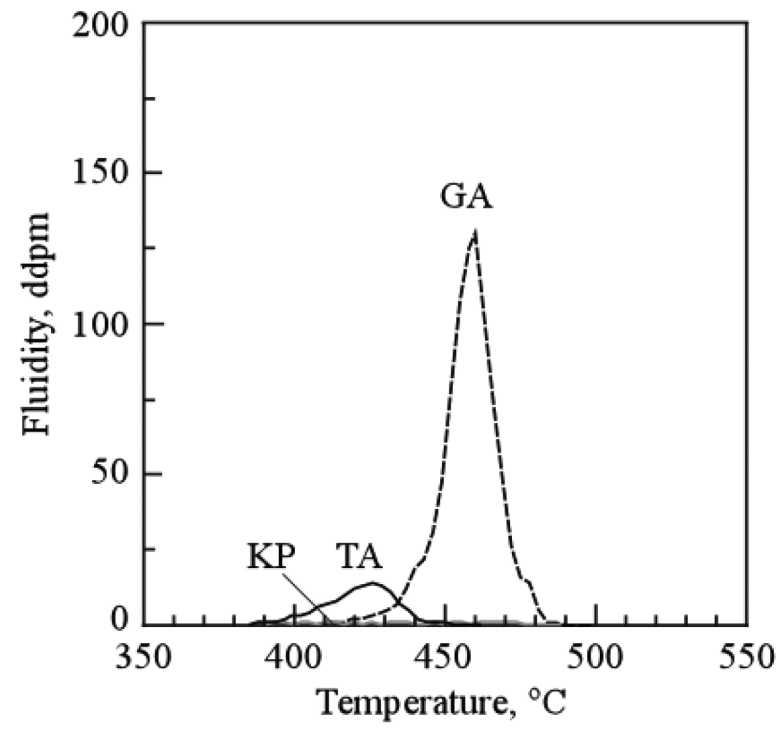

Fig. 1. Gieseler fluidity profile of coals used in this study.
リジン抽出でられた生成物の FT-IRスペクトルは大きく異 なったことから，これら 2 種の溶媒の HPCからの可溶分成 分は異なると言える。

\section{3・3 HPC 可溶分, 不溶分の熱重量減少挙動}

Fig.3 は, HPC, ピリジン可溶分, 不溶分の TG 分析の結果 を示す。 $\mathrm{HPC}$ tG 分析に供したところ, $250,380,450{ }^{\circ} \mathrm{C}$ 付近に重量減少速度のピークが観測された。ピリジン可溶 分単独での分析では $100^{\circ} \mathrm{C}$ 前後にピークが観測され，これ は可溶分表面上に吸着したピリジンの脱離に基因する。ま

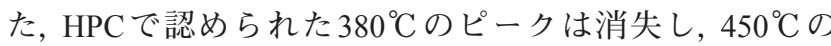
ピーク強度が僅かに減少した。一方，不溶分では約 $250^{\circ} \mathrm{C}$ と $380^{\circ} \mathrm{C}$ 前後のピークが消失し, HPCで認められた $450^{\circ} \mathrm{C}$ 前後のピークは僅かに高温にシフトした。これらの結果 は, HPC 中の低分子成分は主に可溶分に移行したことを指 摘する。

$\mathrm{MeOH}$ 可溶分は, $200^{\circ} \mathrm{C}$ 前後から大幅な重量減少が生じ, $300^{\circ} \mathrm{C}$ に重量減少の速度ピークを与えるプロファイルを示 した。一方 $\mathrm{MeOH}$ 不溶分では HPCで認められた $250^{\circ} \mathrm{C}$ 前後 のピーク強度が減少するとともに, $380^{\circ} \mathrm{C}$ 付近のピークも

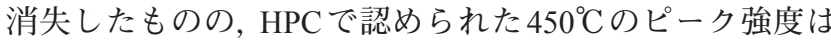
維持された。つまり, $\mathrm{MeOH}$ 処理においても $\mathrm{HPC}$ 中の低分 子成分が可溶分に移行したと言える。 $\mathrm{MeOH}$ 可溶分の重量 減少は200〜 $500^{\circ} \mathrm{C}$ の温度範囲でほぼワンステップにて進 行したことから, HPCピリジン可溶分よりもより低分子成 分に富んでいるものと考えられる。

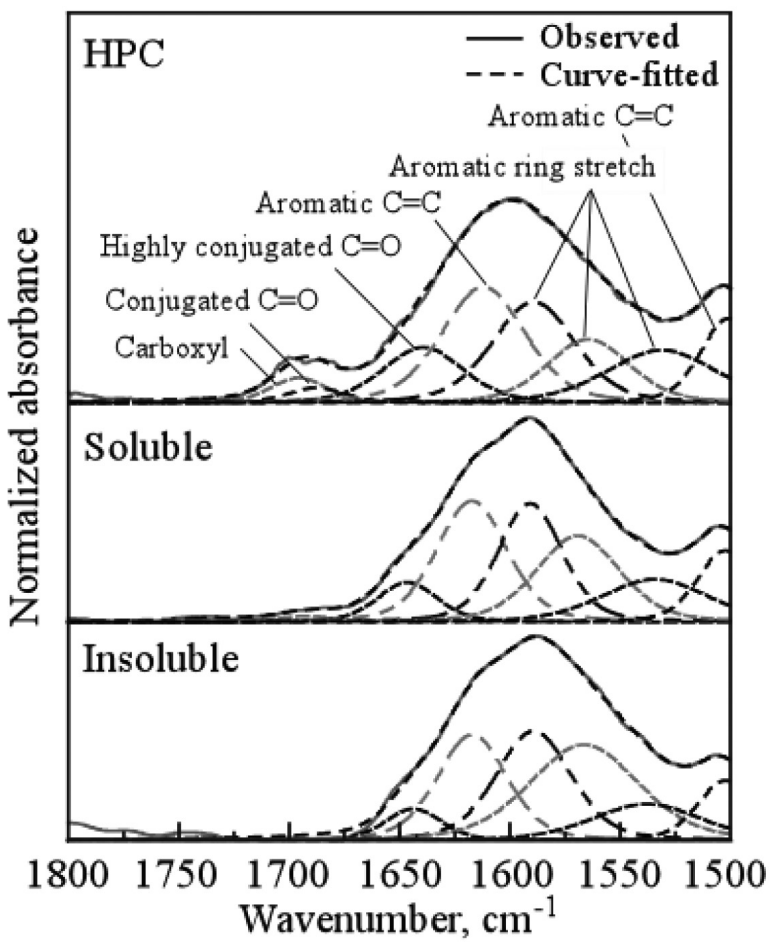

Fig. 2. FT-IR spectrum deconvoluted at $1800-1500 \mathrm{~cm}^{-1}$ of HPC, HPC pyridine-soluble components and HPC pyridine-insoluble components. 
Fig.4は，ピリジン可溶分を化学的に担持した試料なら びに物理的に混合した試料を $\mathrm{TG}$ 分析を示している。いず れも可溶分単独で観測された $250^{\circ} \mathrm{C}$ 付近ピークはほぼ完全 に消失し，また，約 $450^{\circ} \mathrm{C}$ のピーク強度も小さくなり，その 程度は化学担持炭で大きかった。この結果は, 化学的な担 持処理の方が TA炭と可溶分の相互作用を促進しているこ とを示唆している。類似の結果は, $\mathrm{MeOH}$ 可溶分の物理混

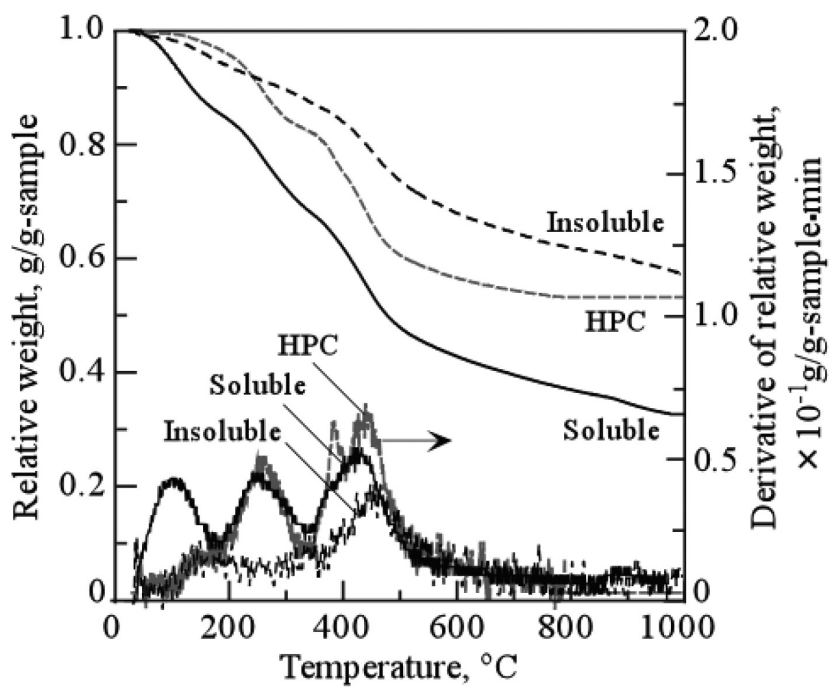

Fig. 3. Thermogravimetric curves of HPC, HPC pyridinesoluble components and HPC pyridine-insoluble components.

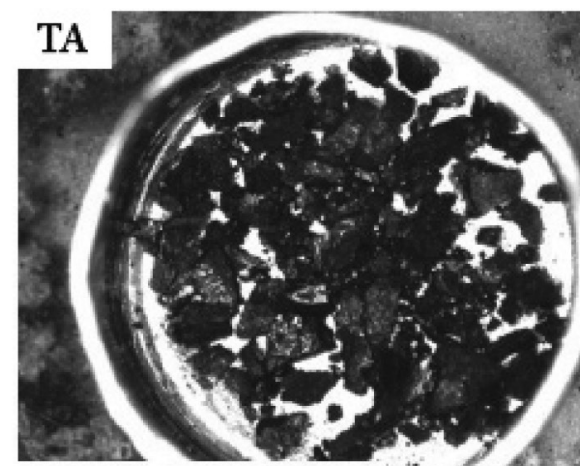

Temperature : $30^{\circ} \mathrm{C}$

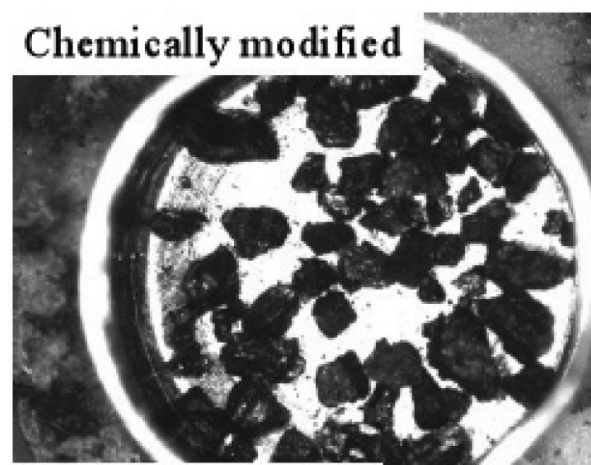

Temperature : $30^{\circ} \mathrm{C}$
合ならびに化学担持炭でも認められ，可溶分で観測された $300^{\circ} \mathrm{C}$ 前後の重量減少挙動のピークはほぼ消失していた。

\section{$3 \cdot 4$ 化学担持炭の流動性}

$\mathrm{TA}$ 試料の流動性を調べるために，ギーセラー試験に供 したところ，ピリジン可溶分担持炭単独のギーセラー試験 では試料充填時に固まらなかった。そのため, 加熱顕微鏡 による測定を実施した。Fig.5は，TAとTAにピリジン可溶

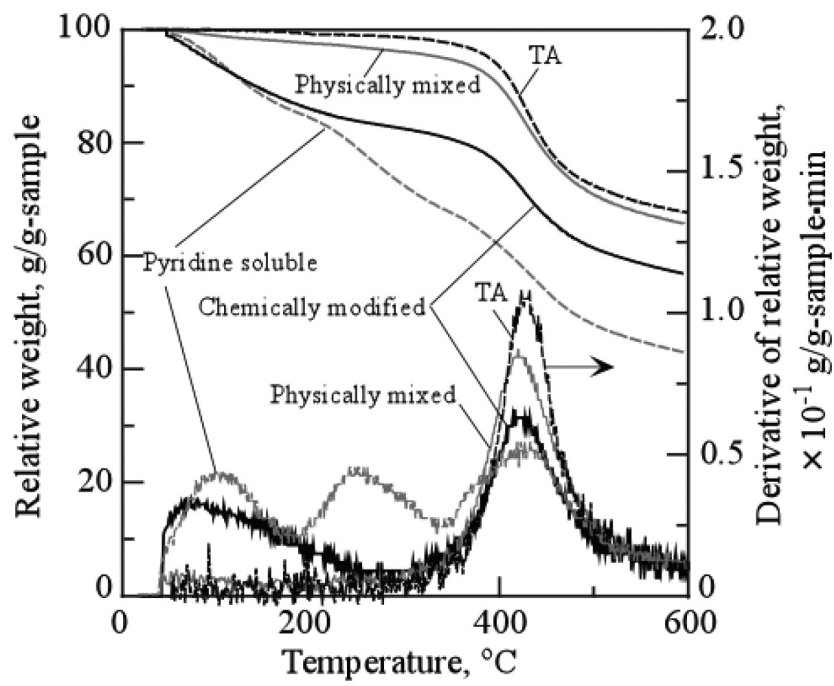

Fig. 4. Thermogravimetric curves of TA, HPC pyridine-soluble components, chemically modified and physically mixed samples.
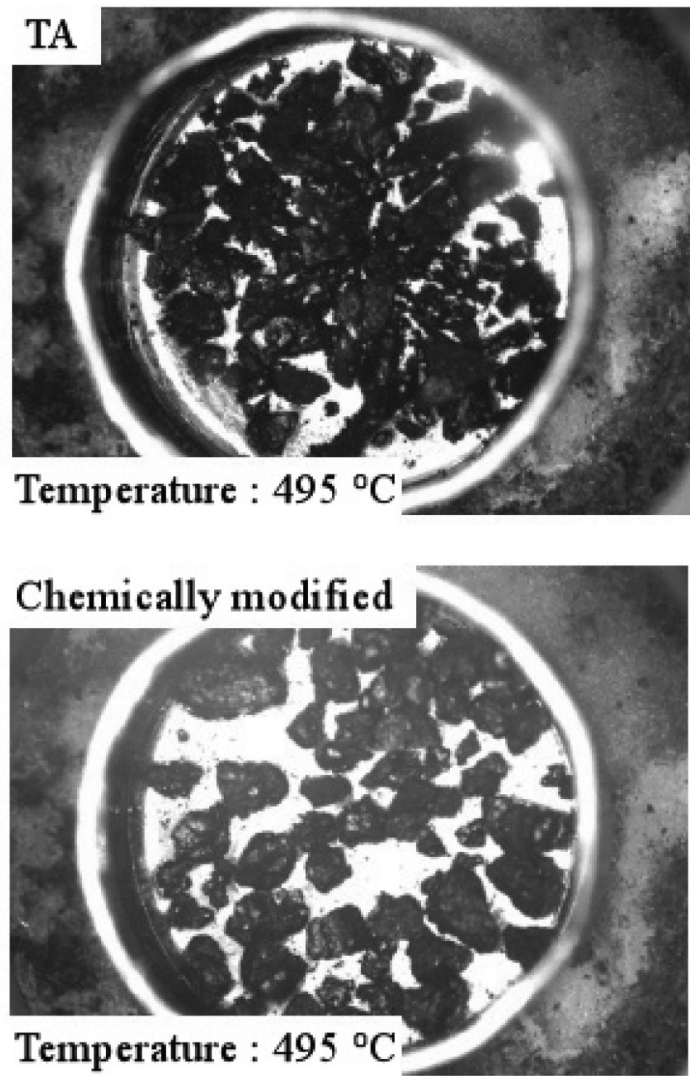

Fig. 5. Microscopic pictures of TA and chemically modified sample during heat treatment of $50^{\circ} \mathrm{C} / \mathrm{min}$. 
分を 15 mass\%化学担持した試料の加熱顕微鏡の結果を示 す。実験の都合上，低速加熱での観察が困難であったため に $50^{\circ} \mathrm{C} / \mathrm{min}$ で行なった。TAや調製した化学担持炭は室温 では角ばった形状をしているのがわかる。TA炭を加熱す ると $450^{\circ} \mathrm{C}$ 付近から粒子の一部が溶融し始め, $495^{\circ} \mathrm{C}$ では若 干の膨張が認められた。一方，化学担持炭では $300^{\circ} \mathrm{C}$ 付近 で一部の粒子が動き, $400^{\circ} \mathrm{C}$ 前後から粒子の溶融が認めら

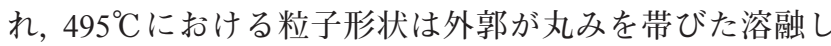
た状態となった。また，その程度はTA炭と比較し大きなも のであった。

ピリジン可溶分担持処理により実際にどの程度の流動 性の改善が生じているのかを数值的に検討するために, 弱粘結炭である BW $\left(\mathrm{C}, 86.6 ; \mathrm{H}, 5.0 ; \mathrm{N}, 2.0 ; \mathrm{S}, 0.60 ; \mathrm{O}^{\text {diff }}\right.$ 5.8 mass\%-daf, ash, 9.6; VM, 57.4 mass\%-dry, MF, $0.30 \log$ $(\mathrm{ddpm}))$ と TA試料を重量比 7：3で混合して測定を行なっ た。Fig.6は, HPCピリジン可溶分を化学担持，ならびに物 理混合した試料のギーセラー流動プロファイルを示す。ま た，得られた流動特性の值を Table 2 に示す。BW-TAでは $420 \sim 460^{\circ} \mathrm{C}$ で流動し， $440^{\circ} \mathrm{C}$ 前後に $\mathrm{MF}$ 值を与えたが，その 值は $0.60 \log (\mathrm{ddpm})$ と非常に小さかった。ピリジン处理炭 の軟化溶融は $410^{\circ} \mathrm{C}$ から認められ, $450^{\circ} \mathrm{C} に \mathrm{MF}$ 值 $(0.78 \mathrm{log}$ $(\mathrm{ddpm}))$ を示した後に $475^{\circ} \mathrm{C} て ゙$ 再固化した。ピリジン处理 炭では未処理炭と比較し, 若干の流動性の向上が認められ たが，これは上述したように，ピリジン処理により石炭の 化学的な構造変化 (含酸素官能基とピリジンの反応) によ り水素結合の開裂が生じたことに基因するのかもしれな ( $^{21)}$ 。可溶分物理混合炭の流動特性はピリジン処理炭とほ ぼ類似したものの, MF值 $(0.95 \log (\mathrm{ddpm}))$ は僅かに増加 した。一方，化学担持炭では試験した試料の中で最も低い

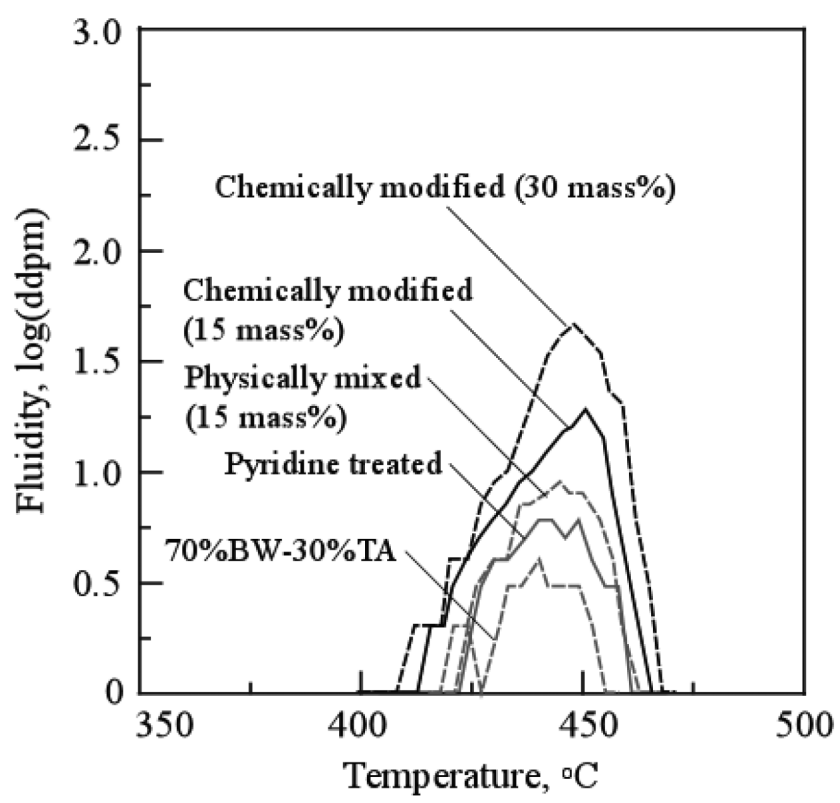

Fig. 6. Gieseler fluidity profiles of BW-TA, pyridine treated, chemically modified and physically mixed samples.
軟化開始温度 (IST : Initial softening temperature) $\left(400^{\circ} \mathrm{C}\right)$ を 示し, $450^{\circ} \mathrm{C}$ で MFを与えた後に $470 \sim 480^{\circ} \mathrm{C} て ゙$ 再固化した。 また, MF值は担持量 15 mass\%で $1.3 \log (\mathrm{ddpm})$ であった のに対し，担持量を 2 倍 (30 mass\%) とすると $1.7 \log (\mathrm{ddpm})$ と BW-TAの2 倍以上に達した。この結果は，化学担持炭で は, 加熱時に可溶成分が石炭と強く相互作用すると言う熱 重量分析での考察を支持する。また，物理混合炭と比較し， 化学担持炭で流動性が大きく向上したのは, 石炭と可溶分 成分の接触性が影響を与えているのかもしれない。

一方, $\mathrm{MeOH}$ 可溶分を化学的に担持した試料ならびに物 理混合した TA試料では，ギーセラー試験の試料充填時に 固まったことから，調製した試料を単独で測定に供した。 そのギーセラー試験の結果を Table 3 に示す。いずれの試 料も390 $400^{\circ} \mathrm{C}$ で軟化溶融し始め, $430^{\circ} \mathrm{C}$ で MF 值を与え た後に $450^{\circ} \mathrm{C}$ で再固化した。 $\mathrm{MeOH}$ 可溶分を化学担持なら びに物理混合した試料の MFは $0.90 \log (\mathrm{ddpm})$ であり，TA $(0.78 \log (\mathrm{ddpm}))$ と比較し若干の増加が認められたが，そ の程度は非常に小さいものであった。これまでに我々は, 粘結炭に種々の含酸素官能基を含む化合物を添加した時の ギーセラー流動プロファイルを調べており，粘結炭のIST よりも低い沸点を有する含酸素化合物の添加でさえも流

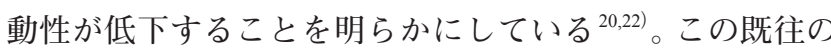
研究では, 含酸素官能基は石炭のISTまでに石炭粒子と相 互作用し，後の流動性に悪影響を及ぼしている可能性が示 唆されている ${ }^{20)}$ 。上述した様に, $\mathrm{HPC} \mathrm{MeOH}$ 可溶分は HPC

Table 2. Summary of Gieseler fluidity profiles of TA samples prepared using pyridine.

\begin{tabular}{|c|c|c|c|c|c|c|}
\hline \multirow{2}{*}{ Sample } & \multicolumn{4}{|c|}{ Temperature, ${ }^{\circ} \mathrm{C}$} & \multicolumn{2}{|r|}{$\mathrm{MF}^{\mathrm{a}}$} \\
\hline & IST $^{\mathrm{b}}$ & MFT $^{\circ}$ & $\mathrm{RST}^{\mathrm{d}}$ & FTR $^{\mathrm{e}}$ & ddpm & $\log ($ ddpm $)$ \\
\hline $\begin{array}{c}70 \text { mass } \% \text { BW-30 } \\
\text { mass } \% \text { TA }\end{array}$ & 420 & 440 & 460 & 40 & 4 & 0.60 \\
\hline Pyridine treated & 410 & 450 & 475 & 65 & 6 & 0.78 \\
\hline $\begin{array}{l}\text { Physically mixed } \\
\text { (15 mass\%-soluble) }\end{array}$ & 410 & 445 & 475 & 65 & 9 & 0.95 \\
\hline $\begin{array}{l}\text { Chemically modified } \\
\text { (15 mass\%-soluble) }\end{array}$ & 400 & 450 & 470 & 70 & 19 & 1.3 \\
\hline $\begin{array}{l}\text { Chemically modified } \\
\text { ( } 30 \text { mass\%-soluble) }\end{array}$ & 400 & 450 & 480 & 80 & 46 & 1.7 \\
\hline
\end{tabular}

${ }^{a}$ Maximum fluidity. ${ }^{b}$ Initial softening temperature. ${ }^{c}$ Maximum fluidity temperature. ${ }^{\mathrm{d}}$ Resolidification temperature. ${ }^{\mathrm{e}}$ Fluidity temperature range.

Table 3. Summary of Gieseler fluidity profiles of TA samples prepared using methanol.

\begin{tabular}{|c|c|c|c|c|c|c|}
\hline \multirow{2}{*}{ Sample } & \multicolumn{4}{|c|}{ Temperature, ${ }^{\circ} \mathrm{C}$} & \multicolumn{2}{|r|}{$\mathrm{MF}^{\mathrm{a}}$} \\
\hline & IST $^{b}$ & MFT $^{\circ}$ & $\mathrm{RST}^{\mathrm{d}}$ & FTR $^{\mathrm{e}}$ & ddpm & $\log ($ ddpm $)$ \\
\hline TA & 400 & 430 & 450 & 50 & 4 & 0.78 \\
\hline $\begin{array}{l}\text { Physically mixed } \\
\text { (10 mass\%-soluble) }\end{array}$ & 395 & 430 & 445 & 50 & 8 & 0.90 \\
\hline $\begin{array}{l}\text { Chemically modified } \\
\text { (10 mass\%-soluble) }\end{array}$ & 390 & 430 & 450 & 60 & 8 & 0.90 \\
\hline
\end{tabular}

${ }^{a}$ Maximum fluidity. ${ }^{\mathrm{b}}$ Initial softening temperature. ${ }^{\mathrm{c}}$ Maximum fluidity temperature. ${ }^{d}$ Resolidification temperature. ${ }^{\mathrm{e}}$ Fluidity temperature range. 
中の含酸素官能基を濃縮した状態で多く含んでおり，その 熱重量減少はTAの軟化溶融が始まる約 $400^{\circ} \mathrm{C}$ までにほほ 終了する。一方, TG 測定の結果から $\mathrm{MeOH}$ 可溶分もピリ ジン可溶分と同様にTAのISTまでに石炭と相互作用して いることは明白である。そのため，低分子成分を多く含む $\mathrm{MeOH}$ 可溶分に抏いても TAのISTまでに $\mathrm{MeOH}$ 可溶分中 の含酸素官能基が石炭に作用することで流動性に悪影響を 与えたものと推測される。つまり，低分子成分による流動 性の向上効果と含酸素官能基による流動性へのネガティブ な効果により, TAの流動性は殆ど変化しなかったものと 考えられる。

\section{$3 \cdot 5$ 化学担持炭から調製したコークス強度}

Fig.7 7 ピリジン可溶分を担持した TA試料 (BWとの物 理混合なし) を $3^{\circ} \mathrm{C} / \mathrm{min}$ で $1000^{\circ} \mathrm{C}$ ま゙加熱して得たコーク スの強度を示す。GAの強度は3.0 MPaで, 破断面には高気 孔率部分が認められたので, 膨張性過多による強度低下 の可能性がある。TA, ピリジン処理炭, 可溶分物理混合, HPC 物理混合炭では，その強度は $1.5 \sim 3.5 \mathrm{MPa}$ の範囲で, 一方, 可溶分化学担持炭では $5.2 \mathrm{MPa}$ に達し, 原炭の 2 倍以 上となった。しかし, 担持量を2倍に増やすと著しい強度 減少 $(1.2 \mathrm{MPa})$ が生じた。上記のように，可溶分導入量を 増やすと MFが大きく増したことから, 強度の低下は膨張 性過多に依ると言える。これは，担持量を 30 mass \%とした 際に, 15 mass\% 担持と比較し, かさ密度の僅かな減少が認 められたことからも支持される。TAや物理混合炭と比較 し, 可溶分化学担持炭では収率やかさ密度が小さくなった が，これは試料調製時に付着したピリジンの脱離によるも のと考えられる。一方で，15 mass\%担持の場合と比較し， $30 \mathrm{mass} \%$ 担持試料から調製したコークスの収率が同程度 であったことは，可溶分成分が乾留過程で石炭と相互作用 し, 固相内に取り込まれたことを強く指摘する。HPCを物 理的に混合した際の強度は $3.5 \mathrm{MPa}$ であり, その值は可溶

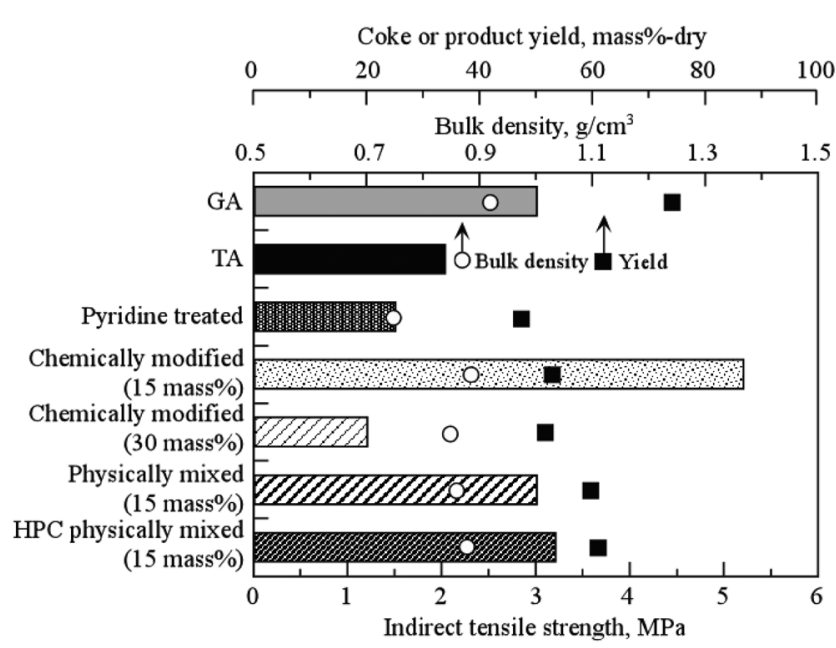

Fig. 7. Properties of cokes and products prepared from TA samples.
分物理混合炭とほぼ同じであった。HPCピリジン抽出物の 熱重量分析の結果からピリジン可溶分は不溶分と比較し, 分子量が小さいと考えられるため $\mathrm{TA}$ へ $\mathrm{HPC}$ を添加した場 合, HPC 中の比較的低分子な成分がコークス強度の増加に 寄与していることを示唆しているのかもしれない。一方， 化学担持炭の強度は物理混合炭と比較し大きくなったが, これは可溶分成分の初期の石炭への分散性の違いに基因す るものと考えられる。つまり, ピリジン溶媒中での石炭膨 潤により生成した空隙内に可溶分成分を担持させること で, 石炭と可溶分の接触性と加熱時の相互作用の程度が向 上し，流動性が増加する結果，コークス強度が増大したと 推測される。よく知られているように，アスファルトピッ チ (ASP) は高強度コークス製造時の粘結材として使用さ れている。ASP添加によるコークス品質向上機構について は，高流動性による粘結成分の補填や相溶性の向上，コ一 クス組織の光学異方性組織の発達などによる基因すると受 け止められている ${ }^{23)}$ 。また, ASP添加炭から製造したコー クスでは気孔形状扎よび気孔壁厚みが変化し，微細気泡の 割合が減少するため，コークス強度が増大することが報告 されている ${ }^{24)}$ ささらに, ASPの微細化により製造するコー クスの強度が向上する ${ }^{24)}$ 。うり, 粘結材の分散性は, コー クス強度に影響を与える因子の一つであると言える。本研 究で調製したHPCピリジン可溶分の化学担持炭では，担持 法としてピリジンに溶解している溶融成分を含浸担持して おり，さらにピリジンの膨潤作用により生じた空隙内に可 溶分が導入され，可溶分と石炭が近接化した状態である。 そのため, ASP と同様の作用 (流動性向上による気孔形状 および気孔壁厚みの変化）が生じ流動性とコークス強度の 改善が生じたものと推測される。以上の結果から, 本手法 により HPCピリジン可溶分を TA炭に化学的に担持するこ とで, 得られるコークスの強度も改善可能であることが見 出された。

ピリジン可溶分担持炭でのコークス強度改善を理解する ため, コークス圧潰試験後の破断面を研磨し, SEM観察を 行なった結果を Fig.8に示す。TA炭では一部軟化溶融した ことに基因する組織が見られたが, 拡大眓で示すように溶 融成分と非流動基質と界面の接触の程度は小さいもので あった。それに対して，可溶分を化学的に担持 (15 mass\%) した試料から調製したコークスでは, 多くの軟化溶融した 組織が観察された。また, 溶融した部分と非流動基質との 界面の接触性が良好であった。このことから, 可溶分の化 学的担持により乾留時の軟化溶融性が向上するとともに, 流動成分と不活性部との接触性が改善され, コークス強度 が増加したものと考えられる。

Fig.9にピリジン可溶分を担持した KP 試料 (BWとの物

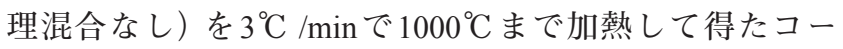
クスの強度を示す。KP, ピリジン処理炭, 可溶分化学担持 15 mass\%から得られた生成物はコークス化しておらず，収 

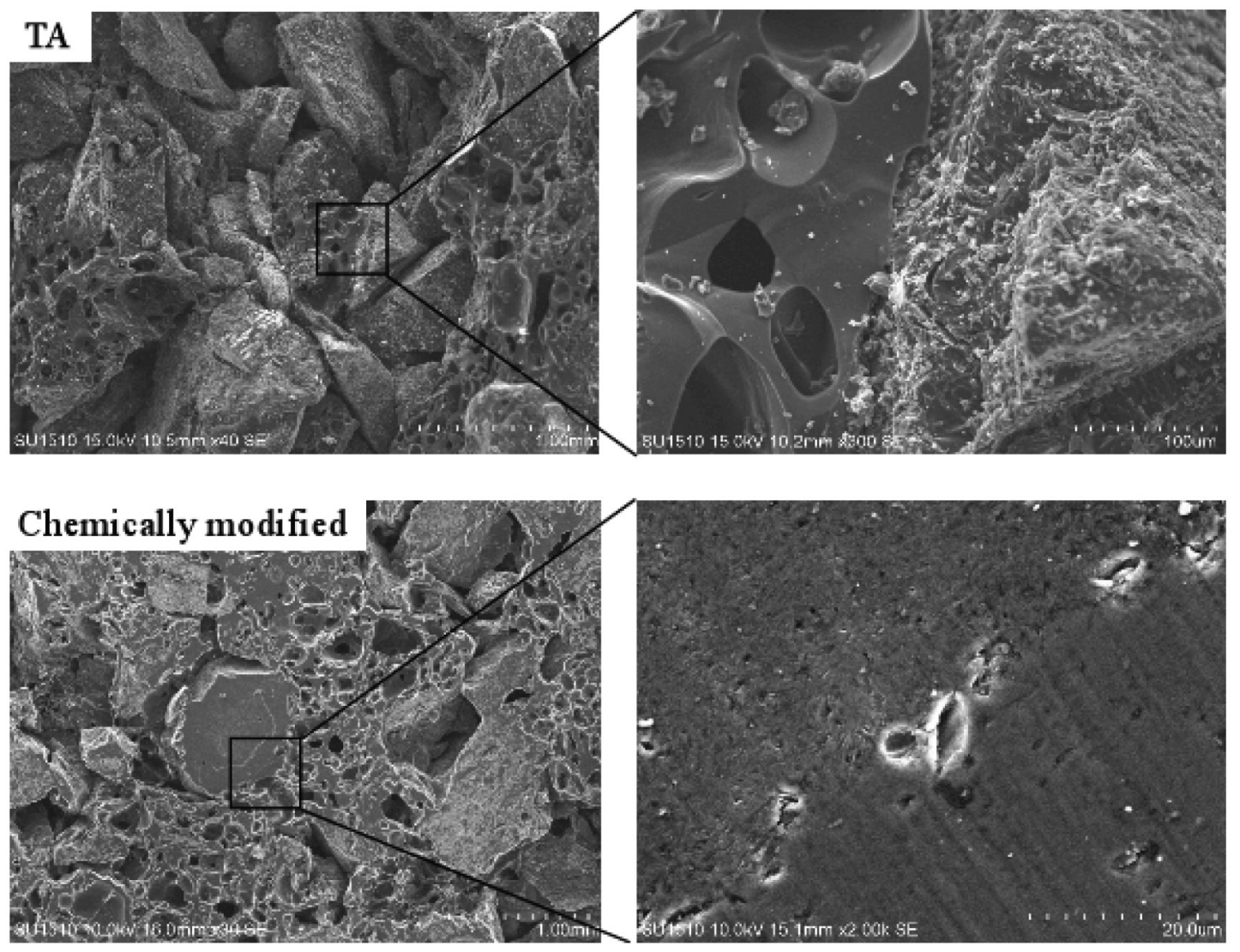

Fig. 8. SEM pictures of cross-section of TA and chemically modified TA sample with HPC pyridine-soluble components.

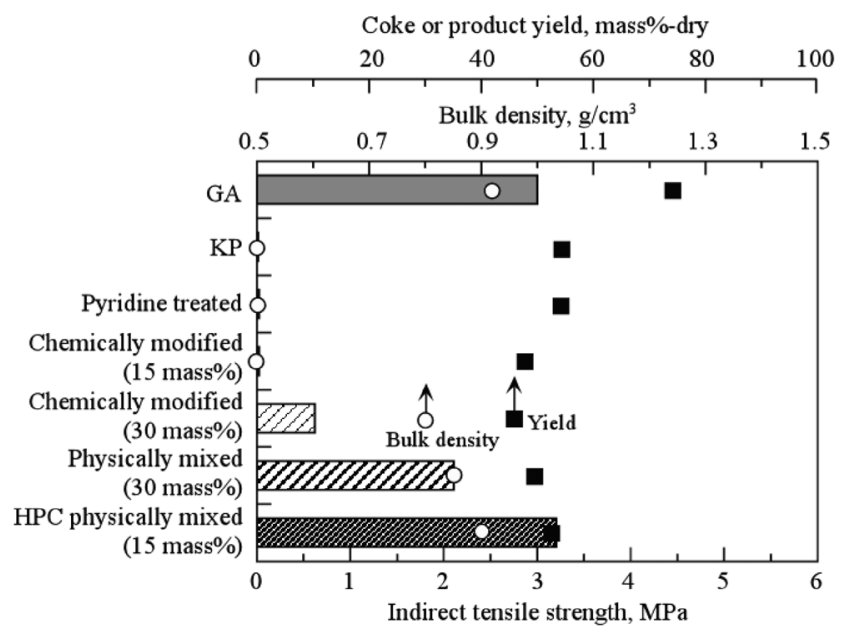

Fig. 9. Properties of cokes and products prepared from KP samples.

率は45〜55 mass\%-dryの範囲にあった。一方，可溶分化学 担持量を 30 mass\%とした場合，コークスを調製すること ができ，その強度は0.5 MPaであった。可溶分物理混合炭 と HPC 物理混合炭でのコークス強度は2.0-3.2 MPaであり, $\mathrm{TA}$ と異なり物理混合炭で大きな強度が認められた。化学 的担持よりも物理混合でコークス強度が増加した理由は現 在不明であるが，流動性を示さないKPのような石炭には， 低分子と高分子成分 (低温で流動性を示す成分と高温で流

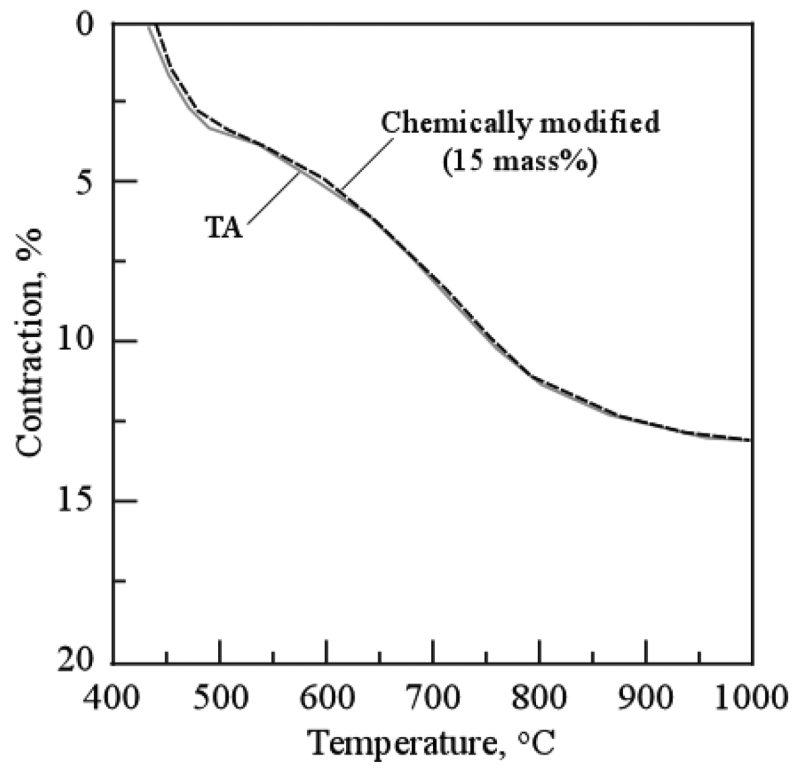

Fig. 10. Contraction profiles of TA and chemically modified TA sample with HPC pyridine-soluble components.

動性を示す成分) の両方を持つHPCのような添加材の利用 がコークス強度向上のために重要であることが示唆され る。

つぎに, TA試料の収縮挙動を分析した結果を Fig.10に 示す。TAならびに可溶分化学担持 15 mass $\%$ の揮発分放出 後の $450^{\circ} \mathrm{C}$ 以降の挙動は試料に関わらずほぼ同じあった。 


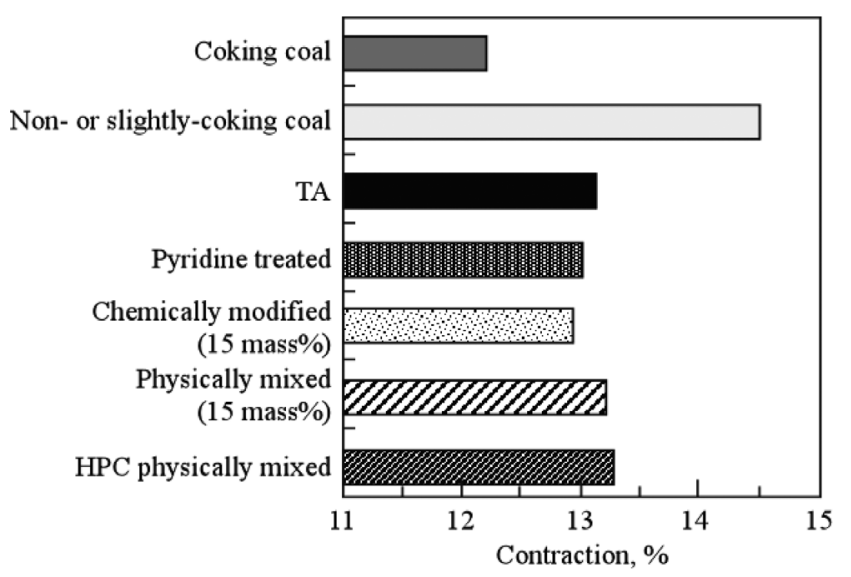

Fig. 11. Summary of contraction rate of TA samples.

類似の結果は, ピリジン処理炭, 可溶分物理混合炭でも認 められている。Fig.11 はFig.10に対応する収縮挙動から求 めた各試料の収縮率のまとめを示す。比較ため，一般的な 粘結炭と微粘結炭の収縮率も併載した。TA炭の収縮率は $13.5 \%$ 程度であり, ピリジン処理炭, 可溶分化学担持炭, 可 溶分物理混合炭, HPC物理混合炭のいずれもほぼ類似の值 を示した。そのため, 本手法は収縮に殆んど影響を与えな いことが判明した。

\section{4. 結論}

本研究では, ピリジンによる石炭中の含 $\mathrm{O}$ 官能基同士の 非共有結合開裂と膨潤により生成した間隙内に HPC由来 の軟化溶融成分を導入し, 乾留時の架橋反応抑制と軟化溶 融成分一石炭間の近接化による流動性増幅の相乗効果を図 り, 高強度コークス製造法を検討した。その結果, 以下の 知見が得られた。

(1) HPCをピリジンで抽出することで得られたピリジン可 溶分と不溶分中では, HPC 中の含酸素官能基の減少が 認められた。その結果, ピリジン抽出により HPC中の 含酸素官能基同士の水素結合を低減可能であると推論 された。一方, $\mathrm{MeOH}$ 抽出ではHPC 中の含酸素官能基 が選択的に可溶分中に移行した。

(2) HPCのピリジン可溶分をピリジンの溶媒膨潤効果を利 用して微粘結炭に担持すると, 可溶分やHPCを物理混
合したものより流動性が向上した。 $\mathrm{MeOH}$ 可溶分を化 学担持した試料では流動性は元の使用と殆ど変らず, 軟化溶融成分担持の効果は認められなかった。

(3) HPCピリジン可溶分を化学的に担持した試料では元 の石炭や可溶分物理混合炭と比較し, 高い強度を持つ コークスを製造できることが明らかとなった。

(4) 可溶分を化学担持した試料ともとの石炭の乾留時の収 縮挙動に大きな違いは認められなかった。

\section{文献}

1 ) N.Okuyama, T.Shigehisa, Y.Nishibata, K.Matsudaira and M.Nishimura: Tetsu-to-Hagané, 92(2006), 213 (in Japanese).

2 ) P.R.Solomon, M.A.Serio, G.V.Despande and E.Kroo: Energy Fuel., 4(1990), 42

3 ) F.Goodarzi and D.G.Murchison: Fuel, 51(1972), 322.

4 ) G.D.Cody, J.W.Larsen and M.Siskin: Energy Fuel., 2(1988), 340.

5 ) L.M.Lucht and N.A.Peppas: Fuel, 66(1987), 803.

6 ) M.Iino, T.Takanohashi, H.Ohsuga and L.Toda: Fuel, 67(1988), 1639.

7 ) J.W.Larsen, T.K.Green and J.Kovac: J. Org. Chem., 50(1985), 4729.

8 ) S.Kawano, M.Abe, K.Shimidu, K.Ogino and H.Honda: Nippon Kagaku Kaishi, 1987(1987), 2301 (in Japanese).

9 ) Y.Sanada and H.Honda: Fuel, 45(1966), 295.

10) N.Y.Kirov, J.M.O'Shea and G.D.Sergeant: Fuel, 47(1968), 415.

11) K.Miura, K.Mae, S.Asaoka, T.Yoshimura and K.Hashimoto: Energy Fuel., 5(1991), 340.

12) K.Miura, K.Mae, T.Yoshimura, K.Masuda and K.Hashimoto: Energy Fuel., 5(1991), 803.

13) K.Miura, K.Mae, K.Sakurada and K.Hashimoto: Energy Fuel., 6(1992), 16

14) K.Mae, N.Hoshika, K.Hashimoto and K.Miura: Energy Fuel., 8(1994), 868.

15) T.K.Green and J.W.Larsen: Fuel, 63(1984), 935.

16) K.Ogino, M.Abe, S.Kawano, K.Shimizu and H.Honda: J. Fuel Soc. Jpn., 66(1987), 778 (in Japanese).

17) N.Sakimoto, T.Takanohashi, Y.Harada and H.Fujimoto: ISIJ Int., 54(2014), 2426.

18) W.Geng, T.Nakajima, H.Takanashi and A.Ohki: Fuel, 88(2009), 139.

19) S.Nomura and T.Arima: Fuel, 105(2013), 176.

20) N.Tsubouchi, Y.Mochizuki, R.Naganuma, K.Kamiya, M.Nishio, Y.Ono and K.Uebo: Energy Fuel., 30(2016), 2095.

21) Z.Wang, Z.Bai, W.Li, H.Chen and B.Li: J. Anal. Appl. Pyrolysis, 87(2010), 45.

22) Y.Mochizuki, R.Naganuma and N.Tsubouchi: Energy Fuel., 32(2018), 1657.

23) Y.Sunami, K.Nishioka, M.Ogawa and Y.Kiritani: J. Fuel Soc. Jpn., 58(1979), 860 (in Japanese).

24) Y.Hayashi, S.Aizawa, K.Uebo, S.Nomura and T.Arima: Tetsu-toHagané, 100(2014), 118 (in Japanese). 